\title{
Factors Corresponded to Health Service Utilization of Chronic Disease Management Program (Prolanis) Patient in Health Center Lateri Ambon City Post-Earthquake
}

\author{
Ervina Imelda Souhaly ${ }^{1}$, Muhammad Alwy Arifin², Darmawansyah², Amran Razak², Anwar Mallongi ${ }^{3}$, \\ Syamsuddin Wadi ${ }^{4}$, Muh. Yusri Abadi ${ }^{2}$ \\ ${ }^{1}$ Reserach Scholar of Magister Program Departement of Health Adminitration and Policy, Public Health \\ Hasanuddin University, ${ }^{2}$ Associate Professor of Departement of Health Adminitration and Policy, Public \\ Health Hasanuddin University, ${ }^{3}$ Professor of Departement of Environmental Health, Public Health Hasanuddin \\ University, ${ }^{4}$ Associate Professor of Faculty Economics and Business, Hasanuddin University
}

\begin{abstract}
The objective of chronic disease management Program (Prolanis) encourages patient with chronic illness to achieve optimal quality of life and $75 \%$ of patient have the "good" results on the specific examination of the disease DM type II and hypertension so as to prevent the onset of disease complications. The purpose of this research is to know the factors related to the utilization of post-earthquake service Prolanis. This type of research is analytic survey research using cross sectional approach design. The population in this study is all prolanis patient who utilize the service in the Public Health center after the earthquake as many as 69 patient. The sampling techniques in this study were the total sampling so that the number of samples in this study of 69 respondents showed that there was no age-old relationship with the utilization of Prolanis services in post-earthquake community health centres $(\mathrm{P}=0,271)$ However, there was a gender relationship (0.000), education $(\mathrm{P}=002)$, and marital status $(\mathrm{P}=0,006)$. Therefore, the Lateri Public Health Center can play an active role and reach out to prolanis patient who utilize the post-earthquake service so that they can maintain and increase the degree of health especially in people with chronic diseases such as hypotensions and diabetes mellitus.
\end{abstract}

Keywords: Prolanis, utilization, post-earthquake, Public health Center

\section{Introduction}

The Chronic Disease Management Program (Prolanis) is an integrated healthcare system and proactive approach that involves patient, health facilities and BPJS healthcare in order to maintain health care for the optimal patient of BPJS Health with the cost of effective and efficient health services. The target of Prolanis activities are all patient of BPJS health with chronic disease especially Diabetes Mellitus (DM) type II and hypertension. This is carried out by first-rate health facilities (FKTP) both in government FKTP and private FKTP. Prolanis aims to encourage patient with chronic illness to achieve optimal quality of life and $75 \%$ of patient have the "good" results on the specific examination of the disease of DM type II and hypertension so as to prevent the onset of disease complications.[1]

The number of sufferers of Diabetes mellitus type 2 continues to increase in Indonesia. Based on RISKESDAS 2018 the prevalence of Diabetes mellitus in population aged $>15$ years for Indonesia is $2.0 \%$. In addition to diabetes mellitus type, hypertension is also a burden of non-infectious diseases that are harmful because of its effects that can spread to other diseases. The prevalence rate of hypertension based on the measurements in population aged $\geq 18$ years in regional health research 2018 increased sharply by $34.1 \%$. [2]

Based on secondary data at the Leteri Public Health center obtained by researchers, the number of pronalists patient registered in Leteri Public health centers as many 
as 134 patient and who utilize prolanis services from January to October 2019 as many as 69 patient per month. [3] in November 2019 until December 2019 there was a decrease in the number of visits in each month as many as 69 patient in 40 patient. The decline in the number of visits occurred in the aftermath of the earthquake that occurred in September 2019 in the city of Ambon caused many people to evacuate so as not to utilize the service of Prolanis in the Lateri Community Health Center. By the time this research aims to determine what factors influence the utilization of the service of Prolanis patient in the health center post earthquake Lateri society

\section{Materials and Method}

The type of research used is an analytical survey using the design of a cross sectional approach. The population in this study is all prolanis patient who utilize the service in the Public Health care center after the earthquake as many as 69 patient. The sampling technique in this study was a total sampling so the number of samples in this study was 69 respondents. Data collection is obtained through a live

\section{Results}

According to table 1, it is revealed that from 69 respondents based on the respondent's age, most of the age group $>60$ years as many as 37 respondents (53.7\%) And the least number of respondents in the age group of 41-50 years as many as 2 respondents or amounting to $(2.9 \%)$. According to gender, respondents were the most female groups of 53 people (76.8\%) And the fewest number of respondents in males is as much as 16 people $(23.2 \%)$. Based on the most recent education is the category SMA/equal to 28 people $(40.6 \%)$ And the least number of respondents were the group did not end the elementary school as much as 2 people (2.9\%). Based on the marital status, the most widely married category of 53 people (76.8\%) And the fewest number of respondents were not married for 2 people $(2.9 \%)$

Table 1. Distribution of Respondents Based on the Characteristics of Respondents from Prolanis patient in the lateri health center post-earthquake in $\mathbf{2 0 2 0}$

\begin{tabular}{|l|l|l|}
\hline Push Factor & Number (n) & Percent (\%) \\
\hline a. Age (yr) & & \\
$30-40 \quad$ & 20 & 28.9 \\
$41-50$ & 2 & 2.9 \\
$51-60$ & 10 & 14.5 \\
$>60$ & 37 & 53.7 \\
\hline Total & 69 & 100 \\
\hline & & \\
b. Gender & 16 & 23.2 \\
Male & 53 & 76.8 \\
Female & & \\
\hline Total & 54 & 100 \\
\hline c. Education & & \\
Not completed in primary school & 2 & 2,9 \\
Graduated from elementary school & 4 & 5.8 \\
Graduated from middle school & 6 & 8.7 \\
Graduated from high school / vocational & 28 & 40.6 \\
school & 19 & 27.5 \\
D3 & 10 & 14.5 \\
Graduated from college & 69 & 100 \\
\hline Total & & \\
\hline
\end{tabular}


Cont... Table 1. Distribution of Respondents Based on the Characteristics of Respondents from Prolanis patient in the lateri health center post-earthquake in $\mathbf{2 0 2 0}$

\begin{tabular}{|l|l|l|}
\hline d. Marital status & & \\
Marry & 53 & 76.8 \\
Divorce & 14 & 20.3 \\
Single & 2 & 2,9 \\
\hline Total & $\mathbf{6 9}$ & $\mathbf{1 0 0}$ \\
\hline
\end{tabular}

Source: Primary Data, 2020

Factors related to the utilization of Prolanis patient service in the Lateri Health center of Post-earthquake

The results of the analysis of the influence of individual characteristics of age, sex and last education of the officer's performance can be seen in table 2

Table 2. Factors related to Utilization of Prolanis patient Services at the Lateri community health center Post-Earthquake

\begin{tabular}{|c|c|c|c|c|c|c|c|}
\hline \multirow{3}{*}{ Research variable } & \multicolumn{4}{|c|}{ Utilization } & \multirow{2}{*}{\multicolumn{2}{|c|}{ amount }} & \multirow{3}{*}{$\mathbf{p}$} \\
\hline & \multicolumn{2}{|c|}{ Make use of } & \multicolumn{2}{|c|}{ Underutilizing } & & & \\
\hline & n & $\%$ & $\mathbf{n}$ & $\%$ & $\mathbf{N}$ & $\%$ & \\
\hline Age Group (year) & & & & & & & \multirow{4}{*}{0.271} \\
\hline Adult & 23 & 71.9 & 9 & 28.1 & 32 & 100 & \\
\hline Elderly & 31 & 83.8 & 6 & 16.3 & 37 & 100 & \\
\hline amount & 54 & 78.3 & 15 & 21.7 & 69 & 100 & \\
\hline Gender & & & & & & & \multirow{4}{*}{0,000} \\
\hline Male & 6 & 37.5 & 10 & 62.5 & 16 & 100 & \\
\hline Girl & 47 & 90.6 & 6 & 9.4 & 53 & 100 & \\
\hline amount & 54 & 78.3 & 15 & 21.7 & 69 & 100 & \\
\hline Education & & & & & & & \multirow{4}{*}{0.002} \\
\hline Basic & 3 & 50 & 3 & 10 & 6 & 100 & \\
\hline Advanced & 51 & 81 & 12 & 19 & 63 & 100 & \\
\hline amount & 54 & 78.3 & 15 & 21.7 & 69 & 100 & \\
\hline Marital status & & & & & & & \multirow{4}{*}{0.006} \\
\hline Married & 43 & 81.1 & 10 & 18.9 & 53 & 100 & \\
\hline Not married / divorced & 11 & 68.8 & 5 & 31.2 & 16 & 100 & \\
\hline amount & 54 & 78.3 & 15 & 21.7 & 69 & 100 & \\
\hline
\end{tabular}


Source: Primary Data, 2020

Table 2 shows that out of the 32 respondents who have grouped adult categories, there are 23 respondents $(71.9 \%)$ That utilize the Prolanis health services in the Lateri Public Health center well and 9 respondents (28.1\%) Who undertakes the use of medical services in the Lateri Public health center while from 37 respondents grouped by elderly there are 31 respondents $(83.8 \%)$ Who utilize the Prolanis service in the Lateri Public health Center and 6 respondents $(16.2 \%)$ Who undertakes the Prolanis service at the Public Health center of Postearthquake. Statistical test results using the chi-square test obtained the value $\mathrm{P}=0.271$, because the value of $p>0.05$ then there is no age group relationship to the utilization of the service patient in the Post Earthquake.

According to category of gender shows that of 16 respondents who have male gender, there are 6 respondents (37.5\%) Utilizing the Prolanis Health Care Center in the Lateri Public health Centre and 10 respondents (62.5\%) Who undertakes the use of medical services in the Lateri Public health center while 53 female respondents are 47 respondents (90.6\%) Who utilize the Prolanis service in the Lateri Public health Center and 6 respondents (9.4\%) Who undertakes the service of Prolanis at the Lateri Public Health Center. Statistical test results using the chi-square test obtained the value $\mathrm{P}=0.000$, because the value of $\mathrm{p}<0.05$ then there is a gender relation to the utilization of the service of the patient in the post-Earthquake Department center.

Based on the education category shows that out of 6 basic educated respondents, there were 3 respondents (50\%) That utilize the Prolanis health services in the Lateri Public Health center well and 3 respondents (50\%) Who undertakes the use of medical services in the Lateri Public health center while from 63 further educated respondents there are 51 respondents (81\%) Who utilize the Prolanis service in the Lateri Public health Center and 12 respondents (19\%) Who undertakes the Prolanis service at Public health centers. Statistical test results using the chi-square test obtained the value $\mathrm{P}=0.002$, due to the value of $\mathrm{p}<0.05$ then there is an education level relationship to the utilization of the Ministry of Prolanis patient in the lateri health center of Post Earthquake.

Based on the marital status indicates that of 53 respondents who are married, there are 43 respondents $(81.1 \%)$ That utilize the Prolanis health services in the Lateri Public Health center well and 10 respondents $(18.9 \%)$ Who is less utilizing the medical service in the Lateri Public Health Center while the 16 respondents who are not married or divorced/widowed there are 11 respondents $(68.8 \%)$ Who utilize the Prolanis service in the Lateri Public health Center and 5 respondents (31.2\%) Who undertakes the Prolanis service at Public health centers. Statistical test results using the chi-square test obtained the value $\mathrm{P}=0.006$, due to the value of $\mathrm{p}<0.05$ then there is a marital status relationship to the utilization of the service of the patient in the postEarthquake Department center.

\section{Discussion}

\section{Age relationship with the use of Prolanis patient} service

Based on adult category age, there are 23 respondents $(71.9 \%)$ That utilize the Prolanis health services in the Lateri Public Health center well and 9 respondents (28.1\%) Who undertakes the use of medical services in the Lateri Public health center while from 37 respondents grouped by elderly there are 31 respondents (83.8\%) Who utilize the Prolanis service in the Lateri Public health Center and 6 respondents (16.2\%) Who undertakes the Prolanis service at the Public Health center of Post-earthquake. This research is not in line with Jenry et al, 2017 which indicates there is age relationship with the utilization of Public health Center service with value $\mathrm{P}=0.004$. ${ }^{[4]}$ The research conducted by Kim \& Hong (2018) stating that the age level does not affect the level of utilization of health care for the elderly with or without chronic illness ${ }^{[5]}$

\section{Gender relations with the use of Prolanis patient} services

Gender can influence in decision making to conduct treatment search. ${ }^{8}$ This is because women need special health services such as pregnancy health services and specific diseases that require women to utilize health care. Another study mentions that gender does not affect people to be able to use health care services. Both men and women have the same risk utilizing health services ${ }^{[6]}$. The results of the above studies show that Bivariate 
was obtained from 69 respondents, consisting of 53 female respondents and 16 male respondents. According to the table above, it can be seen that the utilization of Prolanis in post Earthquake Community Health center is dominated by female gender. One of the factors that make the utilization rate of Prolanis dominated by female types. Statistical test results using chi-square indicate a value of $\mathrm{P}=0.00$ which means the gender relates significantly to the utilization of the prolanis patient in the Lateri public health centers of post-earthquake. The results of research research of Risman et al (2020) which shows that female gender is more utilizing the Ministry of Prolanis in health services UPT Unpad compared to male gender. ${ }^{7}$

The establishment of a relationship with Prolanis patient service

The status of education is closely related to the awareness and knowledge of one, so that the status of education has a significant influence on the utilization of healthcare services. Usually low-educated communities, lacking awareness and good knowledge of the benefits of healthcare services ${ }^{[8]}$

This research shows the educational variables related to the utilization of Prolanis services in the Public health center post-earthquake leteri with a value of $\mathrm{P}=0.001<0.05$. This is in line with the results of the research of Napirah which shows there is a relationship level of education with the utilization of health care in the working area of community health centers of East Coast Poso District of Poso Regency: ${ }^{[9]}$

\section{Marital Status relationship with the use of Prolanis patient service}

Marital Status can improve health for individuals with chronic diseases. [10-16]. The majority of Prolanis patient in the Lateri health center are married. A total of 53 Prolanis patient were married to utilize the Ministry of Prolanis. According to Riaz et All arital status is one of the factors that can control the patient's condition in his chronically-controlled disease management efforts. This research is in line with the Syafa'at et al, 2019 indicates there is a influence of marital status ( $P$ $=0,015$ ) on the utilization of Prolanis in FKTP Depok [11]. Couples or families can be a figure that can help the disease management process. It is not in accordance with the research which et all (2018) that there is no relationship between the status of married than that is $\operatorname{not} \mathrm{P}=0738.5$

\section{Conclusion}

The study concluded that there is no age relation to the utilization of Prolanis services in post-earthquake community health centres $(\mathrm{P}=0,271)$ However, there are gender relations $(0.000)$, education $(\mathrm{P}=002)$, and marital status $(\mathrm{P}=0,006)$. Therefore, the Lateri Public health center can play an active role and reach out to Prolanis patient who utilize the post-occurrence service of the earthquake so that it can maintain and improve the degree of health especially in people with chronic diseases such as hypotensions and diabetes mellitus.

\section{Sourve of Funding : Self \\ Conflict of Ineterst : Nil}

Ethical Clearance : Obtained from the University Ethical clearance committee

\section{References}

1. BPJS Kesehatan, panduan praktis PROLANIS (Program Pengelolaan Penyakit Kronis). 2014, Badan Penyelenggara Jaminan Sosial (BPJS) Kesehatan: Jakarta.

2. Riskesdas, Hasil Utama RISKESDAS 2018. 2018, Kementerian Kesehatan RI: Jakarta.

3. Puskesmas Lateri, Profil Puskesmas Lateri Tahun 2019. 2020, Puskesmas Lateri: Ambon.

4. Londo, J.P., A.A. Tucunan, and F.R. Maramis, Hubungan antara Karakteristik Peserta BPJS Kesehatan dengan Pemanfaatan Pelayanan Puskesmas di Wilayah Kerja Puskesmas Tahuna Barat. KESMAS, 2017. 6(3).

5. Kim, Y.-E. and S.-W. Hong, Health-related effects of the elderly care program. BioMed research international, 2018. 2018.

6. Laili, A.N., E. Riyanti, and S. BM, Faktor-Faktor Yang Berhubungan Dengan Praktik Pemanfaatan Pelayanan Kesehatan Peduli Remaja (PKPR) Oleh Remajadi Wilayah Kerja Puskesmas Bandarharjo Kota Semarang. 2019, 2019. 7(1): p. 9.

7. Ariana, R., C.W.M. Sari, and T. Kurniawan, PERSEPSI PESERTA PROLANIS TENTANG KEGIATAN PROGRAM PENGELOLAAN 
PENYAKIT KRONIS (PROLANIS) DI UPT

LAYANAN KESEHATAN UNIVERSITAS

PADJADJARAN. NurseLine Journal, 2020. 4(2): p. 103-113.

8. Rumengan, D.S., J. Umboh, and G. Kandou, Faktorfaktor yang berhubungan dengan pemanfaatan pelayanan kesehatan pada peserta BPJS kesehatan di Puskesmas Paniki Bawah Kecamatan Mapanget Kota Manado. Jikmu, 2015. 5(2).

9. Napirah, M.R., A. Rahman, and A. Tony, FaktorFaktor Yang Berhubungan Dengan Pemanfaatan Pelayanan Kesehatan Di Wilayah Kerja Puskesmas Tambarana Kecamatan Poso Pesisir Utara Kabupaten Poso. Jurnal Pengembangan Kota, 2016. 4(1): p. 29-39.

10. Henry, S.L., et al., Spousal undermining of older diabetic patients' disease management. Journal of Health Psychology, 2013. 18(12): p. 1550-1561.

11. Anwar Mallongi, Stang, Syamsuar, Muh Fajaruddin Natsir, Ratna Dwi Puji Astuti, Annisa Utami Rauf, Muhammad Rachmat, Abdul Muhithd, Potential ecological risks of mercury contamination along communities area in tonasa cement industry Pangkep, Indonesia. Enfermería Clínica., Volume 30, Supplement 4, June 2020, Pages 119-122

12. Anwar Mallongi, Ezra Limbong, Furqaan Naiem, Hasanuddin Ishak, Syahrul Basri, Muh. Saleh, Aminuddin Syam, Laode Asrul. Health risk analysis of exposure to mercury $(\mathrm{Hg})$ and cyanide $(\mathrm{CN})$ in Kayeli village communities Teluk Kayeli district Buru regency. Enfermería Clínica Volume 30, Supplement 4, June 2020, Pages 427-430
13. Syafa'at, A.W., R.M. Pulungan, and P. Permatasari, Pemanfaatan Prolanis di Fasilitas Kesehatan Tingkat Pertama Wilayah Kota Depok. MEDIA KESEHATAN MASYARAKAT INDONESIA, 2019. 18(4): p. 127-134.

14. Russeng, S.S., Saleh, L.M., Virani, D., Latief, A.W.L., Mallongi, A. The investigation of the lactic acid change among employee of national electrical power plan. Indian Journal of Public Health Research and Development 2018; Volume 9, Issue 1, Pages 361-365

15. Rosmala Nur, Siti Ika Fitrasyah, Anwar Mallongi, Women's Reactions and Health Disorders Caused by Abuse During the Pregnancy-Postpartum Period. Medico-legal Update, January-March 2020, Vol.20, No. 1

16. Muhith A, Winarti E, Perdana SSI, Haryuni S, Rahayu KIN, Mallongi A. Internal Locus of Control as a Driving Factor of Early Detaction Behavior of Servical Cancer by Inspection Visual of Acetic Acid Method. Open Access Maced J Med Sci. 2020Apr 20; 8(E):113-116. https:// doi. org/10.3889/oamjms.2020.4341

17. Mallongi, A., Daud, A., Ishak, H., La Ane, R., Birawida, A.B., Ibrahim, E., Selomo, M., Rahman, S.A. Clean water treatment technology with an upflow slow sand filtration system from a well water source in the tallo district of Makassar. Journal of Environmental Science and Technology, 2017; Volume 10, Issue 1, Pages 44-48

18. Rosmala Nur, Muh. Asep Dwitama, Muh. Fadly, Nurhaya S Patui, Sitti Radhiah, Elvaria Mantao, Anwar Mallongi,. The Culture and Age of First Marriage on Female Teenagers in West Marawola. Medico-legal Update, January-March 2020, Vol.20, No. 1 